\title{
Interest organizations and European Union politics.
}

\author{
GREENWOOD, J.
}

2019

GREENWOOD, J. 2019. Interest organizations and European Union politics. In Thompson, W.R. (ed.)

Oxford research encyclopedia of politics, reproduced by permission of Oxford University Press, article ID 1162. Available from: https://doi.org/10.1093/acrefore/9780190228637.013.1162 
Oxford Research Encyclopaedia of Politics

Section: EU Policy Making

\section{Interest Organizations and European Union Politics}

Justin Greenwood

Aberdeen Business School, Robert Gordon University, Aberdeen, UK

Keywords: EU lobbying; interest representation; European integration; pluralism; civil society; dialogue with civil society

\section{Summary}

Interest representation plays a systemic role in EU policy making and integration, recognised as such in the Treaty on European Union. Interest organisations supply technical and political information to the EU institutions, and EU institutions use interest organisations as agents of political communication. Interest organisations act as a proxy for an otherwise largely absent civil society, with a teeming population of groups advocating for every imaginable cause. Where groups are absent, so EU institutions have stimulated their formation. The result is a pluralist system of checks and balances, although the literature includes findings of 'islands' resembling corporatist practice.

EU institutions have designed a range of procedures in support of 'an open and structured dialogue between the Commission and special interest groups,' now largely packaged as a 'Better Regulation' programme. 
Measures include funding for NGOs, consultation procedures accompanied by impact assessments, a Transparency Register to provide lobbying transparency, and measures for access to documents that enable civil society organisations to keep EU institutions accountable. A multi-level governance system further strengthens pluralist design, making it impossible for any one type of interest to routinely capture the diversity of EU decision making. A key controversy in the literature is how to assess influence, and whether lobbying success varies across interest group type. EU public policy making is regulatory, making for competitive interest group politics, often between different branches of business whose interests are affected differently by regulatory proposals. There are striking findings from the literature, including that NGOs are more successful than business organisations in getting what they want from EU public policy making, particularly where issues reach the status of high salience where they attract the attention of the European Parliament. A key innovation of the Lisbon Treaty involves a European Citizens' Initiative, which takes dialogue between civil society and EU institutions outside the ecosystem inhabited by civil society organisations and EU institutions known as the 'Brussels bubble' and into the member states. 


\section{$\underline{\text { Introduction }}$}

Interest representation has long been identified as a central mechanism in European Union (EU) policy-making and integration. The European Commission, and European Parliament, in particular, seek stakeholders with shared goals who might be in a position to assist in furthering the course of European integration and to help these institutions to achieve specific policy goals, sometimes against a backdrop of member states reluctant to cede sovereignty to the EU. During the 1980s, the focus was upon achieving a Single European Market (SEM), and the European Commission helped to stimulate the formation of stakeholder business groups such as the European Round Table of Industrialists, whose members (Chief Executive Officers of European domiciled multinationals) were well placed to encourage member states to cede the necessary powers to the EU (Green Cowles, 1995). Once a single market, and associated infrastructure policies had been achieved, EU institutions turned to public interest groups as the agenda shifted from market marking to market regulating (Dür, Bernhagen and Marshall, 2015). This is because it is regulatory agendas (such as environmental and social protection) where shared goals between political institutions and NonGovernmental Organisations (NGOs) are likely to arise (Young, 2010). EU institutions often helped to stimulate the formation of groups who could become allies, such as the European Environmental Bureau (Mazey and Richardson, 2005), Finance Watch (for regulation after the financial crisis), and the Platform of European Social NGOs ('Social Platform') (Kohler Koch, 2012). Thus, interest groups have been a source of political 
support, as well as technical information, in the EU political system. They have long held places on various advisory committees that assist the European Commission with the formulation of public policy, sitting alongside the most frequent category of members, experts from the administrations of member states. The thrust has been to seek to ensure that the source of policy information is transparent, pluralised and balanced between different types of interests, although these objectives are not always met.

The Treaty on European Union (TEU) codifies contact between EU institutions and civil society in a frame of participatory democracy, articulated in a section of the Treaty carrying provisions on democratic principles of the EU. Amongst these, Article 10(3) records that 'every citizen shall have the right to participate in the democratic life of the union. Decisions shall be taken as openly and as closely as possible to the citizen'. Article 11(1) states that 'the institutions shall..give citizens and representative associations the opportunity to make known and publicly exchange their views in all areas of Union action'. In similar fashion, Article $11(2)$ states that 'the institutions shall maintain an open, transparent and regular dialogue with representative associations and civil society'. Moreover, Article 11(3) states that 'The Commission shall carry out broad consultations with parties concerned in order to ensure that Union action is coherent and transparent'. But the frame of participation has a different outlook when recast as 'lobbying', particularly in the many EU member states where the term has pejorative connotations out of concern that special interests might be capturing public decision making, 
or skewing it in favour of those with more resources to undertake lobbying activities. The European Commission's 1992 paper 'An Open and Structured Dialogue between the Commission and Special Interest Groups' carried a title which conveyed intentions at an early stage to take the most from a participatory frame whilst limiting the potential scope for harm caused by 'lobbying', set in a light touch regulatory framework underpinned by transparency and minimum standards for consultation. However, most measures only emerged a decade later as part of the European Commission's drive to find popular legitimacy for the EU with its landmark 'White Paper on Governance' of 2001 (European Commission, 2001)

The concept and practice of lobbying at EU level has been politicised by activist professionalised social movements and NGOs. This has also contributed to the regulated context for lobbying, based around transparency, with organisations seeking to influence the public policy of EU institutions highly incentivised to join a public 'Transparency Register' with an associated code of conduct, where lobbying activities, clients (in the case of consultancies) and spending (inter alia) are declared. The novel feature of the register is its breadth of scope, taking in

"activities carried out with the objective of directly or indirectly influencing the formulation or implementation of policy and decisionmaking process of the EU institutions...irrespective of where they are undertaken and the channel or medium of communication used" (Inter Institutional Agreement - IIA, para 7; my emphasis) 
This wide-ranging definition, taking in the likes of events aimed at influencing the climate of opinion in the EU institutions as well as verbal interactions, has been lauded by regulation activists relative to a newly proposed definition based around 'activities which promote certain interests' (Article 3.1, IIA). Separately, there are also 'revolving door' provisions placing restrictions on Commissioners and senior officials taking up positions within 24 months of leaving office. Additionally, European Commissioners, members of their cabinets, and those of the rank of Director General of the Commission, have to publicly disclose their meetings with specific lobby organisations within 14 days. Transparency International have taken these declarations a stage further at its own initiative by collating the data to their interactive 'EU Integrity Watch' website $^{1}$. There, observers can manipulate the data in order to see who are the most regular lobby organisations on which topics, and which Commission senior figures holds the most meetings with lobby organisations. At the time of writing, the Transparency Register is subject to revision, with an inter-institutional agreement dating from 2016 providing the centrepiece for discussion. One of the most notable features involves the inclusion for the first time in the scheme of the Council of Ministers, albeit only at the level of the General Secretariat and the rotating Presidency, and not the permanent representations of member states. Other omissions seem likely to involve whether inclusion on the register should be a pre-condition for a meeting with an MEP, and

\footnotetext{
${ }^{1}$ https://www.integritywatch.eu/
} 
an aspiration among activists that meetings at the operational level (i.e. below that of Director General) of the European Commission be subject to declarations.

There are other transparency related regimes governing EU institutions engagement with civil society, and measures for consultation standards, each covered later. Another measure to achieve 'an open and structured dialogue' involves funding for NGOs working at EU level, which has been subject to contention on the grounds that it may instrumentalise civil society organisations (Hannan, 2010). Some (mainly transnational) NGOs (such as Amnesty International, and Greenpeace), refuse to seek EU funding on the grounds that it might create such a perception. At the other end of the spectrum, some commentators see EU funding as the enabler of an 'associative democracy' (Sanchez Salgado, 2014) which gives a voice to marginalised groups and issues, and helps to address imbalances in interest representation. In this guise, EU funding avoids the need to seek donations from corporate sources with the risks to independence this may bring, and helps to sustain a healthy and diverse population of interest groups in Brussels. This presence can act as an accountability agent in a political system that is based around consensus, with organised civil society playing the role of an 'unofficial opposition' to EU institutions in a political system that lacks one. For instance, according to the EU's Financial Transparency System database ${ }^{2}$, Friends of the Earth Europe received around $€ 1.5$ million in EU funding in 2016 , yet

2 http://ec.europa.eu/budget/fts/index_en.htm 
any visit to its website will find evidence of vigorous criticism of EU policies. Similarly, the European Environmental Bureau received $€ 21.5$ million from the EU in 2017, but this has not prevented it from litigating against the Commission in the European Court of Justice. Nonetheless, the potential constraints are illustrated by a policy decision of the European Women's Lobby not to litigate against the Commission in view of the funding it receives from that source (Sanchez Salgado, 2014).

\section{A Market Place of I deas?}

An EU interest group population along pluralist lines is sought by EU institutions, aimed at ensuring the articulation of interests and counterveiling interests in a public EU policy debate, where diversely comprised interest groups act as a proxy for an otherwise absent public. In this guise, what matters is the establishment of a wide range of groups, with little sense in placing barriers to the formation of groups through accreditation criteria (Kohler Koch, 2010). Whilst there is no authoritative count of the number of groups active at EU level, the Transparency Register provides a head-count of organisations (and self-employed individuals). Here, the main incentives to join the register involve access to apply for a one-year pass to European Parliament buildings, the requirement to be on the register in order to get access to senior levels in the Commission, and to be a member of a Commission Expert/Advisory group or to be invited to an expert hearing at the European Parliament. 11,820 entities are currently ${ }^{3}$ on the register, although this is not an

\footnotetext{
${ }^{3}$ Figures as of 11.9 .2018
} 
authoritative figure as access to the register is by self-publication (albeit with meta oversight) and organisations have diverse reasons (including publicity seeking) to publish an entry, not all connected with EU lobbying. Universities, and some regional government authorities, sit alongside some unusual bedfellows from far-flung corners of the globe as well as the 'usual suspects' of core lobbying organisations established at EU level with a Brussels base. NGOs and an active media at EU level provide oversight of the Register, drawing to the attention of the EU institutions potential data errors. The 'usual suspects' include the number of organisations with an office in Brussels (3751) (some of which are Belgian national organisations), and the number of individuals who have an access pass to the European Parliament buildings (7068). These figures may provide the best available estimate of active lobbyists, if partially incomplete because they exclude lobbyists travelling from the member states for infrequent visits. According to Transparency Register data, there are four consultancies, three trade associations and one company (Google) which spend more than $€ 5$ million on lobbying EU institutions. Most of this is accounted for by staff costs, with $15^{4}$ organisations reporting employing 25 full-time equivalent staff or more engaged in EU lobbying activities.

A key debate has been whether there is biased representation in practice towards one type of interest or another. Activist groups point to the greater number of entries in the producer categories on the EU Transparency Register and elsewhere, but this fails to take into account

\footnotetext{
${ }^{4} 68$ organisations report doing so, but once 'wildcard' entries (such as the inclusion of a total workforce) are stripped out as well as think tanks, around 15 core EU lobbying organisations are included.
} 
the ways in which business interests have different preferences over the detail of regulatory standards, often pitching one segment of business interests against another in competitive lobbying battles. For instance, car parts suppliers are supportive of a high regulatory standard for reduction in $\mathrm{CO}^{2}$ emissions as they have the technologies to produce the standard, whereas car producers don't want to bear the costs and prefer lower regulatory standards. Car producers are divided on how much this matters, as producers of smaller cars have an easier time meeting the emission standards than large car producers. Intra-business competition can even take place at the level of the firm, with different product divisions in a single company affected in diametrically opposite ways, leaving multinationals mute (Hart, 2010). Activist groups have also similarly made the Commission's Expert and Advisory groups the subject of considerable scrutiny, focusing on overall numbers of business members and case studies of imbalance (Vassalos, n.d.), although other analyses have found an overall more pluralistic composition when examining the total population of groups (Gornitzka \& Sverdrup, 2011).

At the systemic level, the EU has a pluralist design that makes it difficult for regulatory capture. Its three legislative institutions are diversely constituted, with 28 Member States, 8 political parties, and 34 policy departments of the European Commission. There have been claims that business interests are more successful in their lobbying (Dür and De Bièvre, 2007), whilst Klüver finds that lobbying success does not vary systematically across interest group type (Klüver, 2012). Greenwood found that cohesion within policy sectors was a strong predictor of 
business unity, with highly concentrated (fewer interests to organise) commodity product sectors (where the nature of the product is not a source of differentiation, e.g. chlorine, petrol) the most cohesive (Greenwood, 2002). The ability of NGOs to work together in coalitions, often sharing back-office facilities in 'NGO houses' in Brussels, bely a greater degree of shared outlooks among NGOs than business organisations. Trade Unions also have a higher degree of cohesion than pan-business interests (Greenwood, 2017). At the case study level, there are contradictory findings. Kurzer and Cooper's claims of bias towards business demands on the renowned EU food information labelling legislation has a counter retort by Hoff et al, who found that the European Parliament changed the file in favour of consumer interests in a significant number of ways (Kurzer and Cooper, 2013; Hoff et al, 2015). Individual authors have also changed their position on the question of interest group influence, switching from seeing a bias of business influence (Dür and De Bièvre, 2007) to a more pluralist outlook. Thus, Dür et al undertook an analysis of the positions of more than 1,000 non-state actors on 70 legislative acts proposed by the European Commission between 2008 and 2010, strikingly finding NGOs to be more successful than business organisations in achieving their policy goals, (Dür, Bernhagen and Marshall, 2015). Boräng and Naurin similarly found that

"the common picture of Brussels - and in particular the Commission - of being in the hands of big business is not confirmed by this study. On the contrary, civil society actors are more likely to share 
views with the Commission officials of what is at stake in legislation compared to business." Boräng and Naurin, 2015, 514)

Dür et al, and Boräng and Naurin, found that business interests were only successful where conflict is low and issues remain technical and below the radar of public saliency in the European Parliament. Dür and Mateo found that interest groups frame issues that resonate in public opinion, encouraging an active public, bringing in other like-minded interest groups to the fray, and deterring lobbying by business groups (Dür and Mateo, 2014). A shared norm in the study of interest groups anywhere is that the salience of an issue is a key predictor of 'who wins' in lobbying battles; where salience is high, so public interests tend to be more successful as they encourage political institutions to follow public opinion. Klüver et al place emphasis on contextual factors, including the salience and complexity of an issue, as well as whether a change to the status quo is involved, the type of policy (which regulatory policies producing competitive interest group politics), and the size of coalitions (where larger coalitions are more successful) (Klüver, Braun \& Beyers, 2015). These factors were also considered by Mahoney in a comparison between the United States and the European Union (Mahoney, 2007). Key differences which emerge are that the European Commission's legislative monopoly means that its policy proposals almost always lead to a policy outcome, whereas in the US, where a Member of Congress can propose an initiative, few initiatives end up as law, not least because of the rule whereby if a proposal does not move forward in the two year Congressional session, it is automatically deleted and needs to be 
reintroduced. EU policy proposals are more likely to lead to legislative compromises because of the diversity of components in legislative institutions, whereas the US is more likely to be based on a 'winner takes all' scenario. In the US, private funding of election campaigns create incentives for elected officials to be more responsive to donors (Mahoney, 2007).

Whilst one set of authors contend that interest group type (business, NGOs etc.) matters in explaining policy outcomes (Dür, Bernhagen and Marshall, 2015); Klüver contends to the contrary with her emphasis on contextual factors (Klüver et al, 2015) in explaining policy outcomes. There is also a lively debate about the methodologies of assessing influence (Dür, 2008; Klüver, 2013; Bunea and Ibenskas, 2015; Klüver, 2015). On the basis that access is a pre-condition for influence, one indicator has been to assess levels of access to EU institutions, theorised in terms of the supply of and demand for access goods such as technical and/or political information (Bouwen, 2004). This method has its critics, not least because of the chasm presented between political access and influence. Dür identifies three methods of assessing influence: process tracing, assessing attributed influence, and gauging the degree of preference attainment. The first of these, process tracing, seeks to 'uncover the steps by which causes affect outcomes' (Dür, 2008: 562), but the identification and interpretation of these raises its own problems, as well as issues of generalisability from a single or small number of cases. Attributed influence involves surveys of self-assessment or that by well-informed observers, but is inevitably subjective. Preference 
attainment compares policy outcomes with stated preferences, but which may reveal little about cause and effect.

\section{Pluralism and Corporatism}

An early strand to the literature debated whether there could be a corporatist mode of interest intermediation at EU level (Greenwood, Grote and Ronit, 1992; Obradovic, 1995; Gorges, 1996; Falkner, 1998). This was stimulated by a keynote article from pioneers of corporatist analysis, which concluded that the conditions for corporatism were not present at EU level because of the lack of 'state-like' properties of EU institutions (Streeck and Schmitter, 1991). Whilst there was little dispute that corporatism did not exist at the systemic level, the literature sometimes found 'islands' or features which resembled corporatist practice at EU level, particularly in the field of labour market ('social') policy where some actors assumed responsibility for the implementation of policy goals. A 'social partnership' involving bilateral dialogue between business and labour groups was institutionalised in the EU Treaties in the 1990s, which bestowed powers upon representative groups to conclude agreements which would become legislation, fuelled much interest among observers (Compston and Greenwood, 2003) but few tangible results. The European Commission briefly (1997; 2001) flirted with the idea of a system that would give special privileges to groups that could 'demonstrate their representativeness and capacity to lead debates' (European Commission, 1997; 2000). This was soon abandoned because of the difficulties experienced from social partnership in establishing and assessing 
measures of 'representativeness,' let alone 'leadership', and because the idea found widespread disfavour, not least from the European Parliament. Nonetheless, civil society groups have organised themselves into 'families' (such as the Green10 group of ten environmental NGOs working at EU level) for regular (up to bi-monthly) meetings with the European Commission, whose boundaries of membership are patrolled by the family, and whose members take on funded projects for EU institutions. In these respects, aspects resembling corporatist practice can be found in pockets at EU level, even if corporatism at the systemic level is unlikely, and a systemic level of pluralism preferred. Commentators have used the qualification of 'elite pluralism' (Coen, 1998; Eising, 2007) and 'chameleon pluralism' (Coen and Katsaitis, 2013) to characterise the relationship between EU institutions and organised civil society.

The European Commission's White Paper on Governance of 2001 (European Commission, 2001), focused on finding legitimacy for the European Union, gave rise to a series of procedures to structure the dialogue with outside interests in the frame of a participatory democracy. These procedures have gradually evolved into a collective package known and prioritised during the current term (2014-2019) of the European Commission as a 'Better Regulation Agenda', part of which is about removing legislation deemed as unnecessary, and part of which 'is about designing and evaluating EU policies and laws transparently, with evidence, and backed up by the views of citizens and stakeholders' (European Commission, 2018a). In a signal of its priority, the agenda is chaired by the Senior Vice President of the European Commission. Better 
Regulation also has as one of its core objectives the systematic evaluation of EU legislation under its Regulatory Fitness and Performance (REFIT) programme, and is open to the public for suggestions as to how to streamline EU legislation.

Better Regulation involves a set of procedures from evaluation to policy inception. The Commission issues a public Legislative Work Programme a year in advance, to give all stakeholders notice of upcoming legislation. Initial ideas, called 'roadmaps' and 'inception impact assessments', are open for feedback for 4 weeks. These are followed by public consultations, open on a dedicated website for a response period of 12 weeks. Once the European Commission has finalised its legislative proposal and submitted it to the European Parliament and Council, there is a further consultation period of 8 weeks, following which the contributions will be passed on to the Parliament and the Council. Where the legislation involves draft delegated and implementing acts, the consultation period is open for 4 weeks.

How might the Better Regulation agenda be classified? Are the procedures primarily about the technical quality of public policy (output legitimacy), or are they more about the legitimacy which comes from opportunities to participate in the shaping of public policy (input legitimacy). Schmidt introduces a special category, 'throughput legitimacy', which is about the robustness and quality of the procedural measures themselves, and which she uses to characterise the EU system of engagement with outside interests (Schmidt, 2013). This has its 
advantages, because it contains elements of both output legitimacy and input legitimacy, whilst distinguishing itself from both. Another adaptation is a preference for the term 'participatory governance', as distinct from the challenging criteria for the presence of a 'participatory democracy' (Kohler Koch and Quittkat, 2013), in which governing with the participation of stakeholders is central. There is a debate as to whether procedures simulate political competition and contestation by a wide range of participants, or constrain civil society organisations by forcing them to operate within the confines of EU institutions in a system of participatory governance, in which consensus seeking is the overarching principle (Kohler Koch, 2012).

Alongside the Better Regulation package, a central measure that underpins the relationship between political institutions and civil society is transparency. Article 15 of the Treaty on Functioning of the European Union (TFEU) states that 'In order to promote good governance and ensure the participation of civil society, the Union's institutions, bodies, offices and agencies shall conduct their work as openly as possible.' Expert and Advisory groups now have a register on Europa, where members (and any potential conflicts of interest) are identified. The Transparency Register was another plank in the transparency regime, but perhaps of greatest significance was the introduction by EU institutions in 2001 of a Regulation on Access to Documents, which provided a means of addressing information asymmetries between EU institutions and civil society. The measure is enshrined in Article 42 of the Charter of Fundamental Rights of the EU, as well as Article 15(3) of the TFEU. It 
allows any EU legal person to request documents held by EU institutions, subject to certain safeguards, and to receive a reply within 15 working days. Most requests are made of the European Commission, to whom, in 2016 there were just over 6,000 applications for access to documents.

Given the potential for the measure to contribute to political accountability, it is worth examining the sources of requests for access to documents. The Commission estimates that almost $40 \%$ of requests came from citizens, $21 \%$ from academic institutions and think tanks, $13.5 \%$ from legal professionals, $12 \%$ from civil society organisations, $10 \%$ from companies, and 6\% from journalists (European Commission, 2017). Over time, there has been an increase in use of the mechanism by citizens, reflecting its greater familiarity by an elite public. A specialised NGO (Access Info Europe) has established a web site, 'Ask the EU.org', to facilitate use of the instrument and dissemination of its results. In 2016, full access to the requested documentation was given in almost $61 \%$ of cases, rising to more than $80 \%$ when partial access was given. Those who are dissatisfied with the outcome may take a case to the European Ombudsman, who fielded 21 complaints against the Commission's handling of requests for access to documents in 2016. The Ombudsman office has always been particularly active on cases involving transparency, often working closely with transparency activist NGOs to expand the boundaries of regimes (Greenwood, 2014). The boundaries have been centred on the interpretation of various grounds to deny access, of which the most politicised are for the protection of international relations, and the integrity of the EU decision-making process. There have also been a 
number of cases that have reached the General Court of the European Court of Justice, whose judgements have generally favoured the appellant. The measure has been applied retroactively, i.e. to documents before 2001, and to documents originating with third parties. Collectively, these factors help to redress information asymmetries between political institutions and civil society, and enable civil society organisations to keep EU institutions accountable.

\section{An open and structured dialogue?: Consultation}

A centrepiece in the Better Regulation package involves the procedures for consultation, based in Article 11(3) of the TEU, as well as an annexed protocol to the Treaties which states that 'before proposing legislative acts 'the Commission shall consult widely'. Consultations are an embedded component of impact assessments, which accompany each legislative proposal. A Commission Communication on consultation standards dating from 2002 states that the guiding principle for the Commission is that of 'a voice but not a vote'. There are various instruments for consultation, ranging from White and Green Papers, questionnaires, expert and public hearings, and citizens' dialogues, but the cornerstone of most consultations involves the use of 12 week open public consultations on a dedicated website on Europa, accounting for $92 \%$ of all impact assessments in 2017 (European Commission, 2018b). A glance through these at any one time demonstrates how technical most of the subjects are on which legislation is proposed, suited for expert audiences rather than a wider public audience, but occasionally a consultation grabs public 
attention. The most responses to a public consultation were 4.5 million, in 2018, on the subject of abolishing harmonisation of daylight saving time. Many such subjects tend to grab the imagination in a particular member state, with, for instance, Germany accounting for around $70 \%$ of the responses on daylight saving. On more technical subjects, the Commission will select from the responses to the open public consultation the main stakeholders, and unique mainstream contributions, and draw the contributors together for a detailed technical policy discussion. In $2017,89 \%$ of impact assessments had consultations targeted at particular groups of stakeholders and additional to the open public consultation (European Commission, 2018b). A Regulatory Scrutiny Board, comprised of seven full time external and internal members, monitors the quality of consultations undertaken, with powers to require the Commission to repeat unsatisfactory elements of the consultation. The Board's assessments are made public; it issued negative assessments for $43 \%$ of impact assessments in 2017 , with failings corrected at the second attempt in many of these cases (European Commission, 2018b). A policy proposal cannot proceed without an approved impact assessment. At the conclusion of the consultation process, the European Commission is supposed to publish a report on the consultation exercise, which in its best guise would give justifications for policy choices made on the basis of input during the consultation phase, and in doing so contribute to input legitimacy. The responses to the consultations should also be published. In $2017,92 \%$ of impact assessments reported on consultation findings. However, earlier studies have found the implementation of consultation responses and reports to be highly variable (Quittkat, 2011). 
Taken as a whole, the measures create 'an open and structured dialogue' between the Commission and special interest groups, with oversight, providing for a pluralistic system of interest representation populated by a diverse range of interest organisations in the 'Brussels microcosm'. Organisations with a Brussels base have the ability to collect policy relevant information, increasingly through formal procedural channels. An important exception involves 'Trilogues' - three way dialogues between the European Parliament, Council of Ministers, and European Commission - which are an informal means of inter-institutional conflict resolution used to reach early legislative agreement on almost all files, held in a secluded setting, typically over the course of three to four meetings. The share of co-decision files adopted in first reading rose from $28 \%$ in in the 1999-2004 legislature to $84 \%$ in the 2014-19 legislature (European Parliament, 2017). Their secluded nature is problematic, because there is no public sight of the trade- offs which are made between the institutions. It also means that networks of contacts are the main way of acquiring information as to the progress of a legislative file, privileging those with a base in Brussels over those trying to follow legislative files from the member states. EU institutions may involve civil society organisations in legislative files when they are seeking to influence the position of other institutions during the course of trilogue negotiations. This is commonly the case with the European Parliament, with a finely tuned political antenna, whose negotiators enter into trilogue agreements with an approved (at committee and plenary level) negotiating mandate. As the people's tribune, the European Parliament prioritises public facing issues 
in a legislative file, tending to give way to the Council on technical issues that are less amenable to public discussion (Roederer-Rynning and Greenwood, 2017). Rasmussen finds that the influence of civil society organisations in the European Parliament is variable. Over four case studies, Rasmussen examined the influence of business in the European Parliament, and found it to vary by a number of factors. These include the degree of business unity over an issue, the extent of salience (where business influence is greater over issues of low public salience), and the extent of experience of the individual committee of the European Parliament with the co-decision making procedure. Where a committee was an established co-decision committee it was more used to playing the role of the legislator and thus more likely to adopt moderate positions, whereas where a committee was new to co-decision it may be stuck in the mind-set of opposition because it lacked the responsibility of its positions become legislation. In these circumstances, committees with less codecision experience than others would be less likely to take up positions that were favourable to business (Rasmussen, 2014).

\section{The European Citizens' Initiative (ECl)}

The significance of the public salience of issues to the functioning of the EU political system is present in attempts by EU institutions to improve participative legitimacy. Article 11(4) of the Treaty on European Union introduced a new mechanism whereby 
Not less than one million citizens who are nationals of a significant number of Member States may take the initiative of inviting the European Commission, within the framework of its powers, to submit any appropriate proposal on matters where citizens consider that a legal act of the Union is required for the purpose of implementing the Treaties.

These powers make it an agenda-setting measure only, bearing little comparison with measures to be found elsewhere (such as in California) where there is compulsion upon political institutions to act. Nonetheless, its limited powers are to be understood in terms of a comparison with the limited powers of the European Parliament to initiate legislation; it was a deliberate design feature of the $\mathrm{ECl}$ that its powers of initiation should not exceed those of the European Parliament (Karatzia, 2017; Vogiatzis, 2017). It also has significance in being the world's first transnational initiative Five initiatives have to date achieved the threshold of 1 million signatures on a subject 'within the framework of EU powers' within 12 months, from a minimum of 7 member states (with weighted thresholds per member state). Reaching such a status gives the organisers the right to a meeting with the European Commission, and subsequently to a public hearing in the European Parliament. In none of these cases was the Commission able to completely meet the demands of $\mathrm{ECl}$ organisers, but in two cases (Right to Water; Ban Glyphosate) the Commission committed to actions related to the demands of the campaign. The significance of the measure may lie more in the effects of public campaigning for signature collection, and the breadth of issues they bring to EU politics. 
There are five initiatives currently open for support, 26 failed to reach the signature threshold, and 15 initiatives were withdrawn by the organisers. Seasoned observers of the initiative estimate that it takes five conversations to convert into one signature (Greenwood and Tuokko, 2017). 8 million signatures have so far been collected by $\mathrm{ECls}$, making for an estimated 40 million conversations on EU related issues in the member states. Subjects introduced by $\mathrm{ECI}$ are more diverse than those routinely proposed by the European Commission, including calls: to legalise cannabis; for an end to the caging of animals; for a permanent status to EU citizenship; for an end to hunger; measures to help refugees; stop plastic in the sea; protecting the institutions of marriage and the family; equal treatment for all transport workers; an end to front companies; the European free vaping initiative; and criminalising ecocide.

The legal framework of the $\mathrm{ECl}$ is set up for transnational campaigning, with the requirement for registration being the establishment of an organising Citizens' Committee comprising seven citizens from seven different member states. This makes the measure ideally suited to students and recent students, and particularly ERASMUS students with a range of transnational contacts and a transnational outlook. The members of Citizens Committees are disproportionately in the 21-30 year age bracket (European Parliament Research Service, 2015). The ECl is appealing to this age cohort with its opportunities for experimentation and adventure, transnational fellowship, public campaigning, the deployment of discourse, communication and e-skills (Greenwood, 2019). They have brought largely new campaigns and new campaign teams to the EU policy 
agenda (Bouza Garcia and Greenwood, 2014), although inevitably some campaigns have their origin with civil society organisations working at EU level. In the early days, the European Commission actively discouraged Brussels based NGOs established at EU level from launching initiatives (EurActiv, 2011), in the hope that new campaigners would come forward. Bouza Garcia and Greenwood found that consensual campaigns were more likely to be associated with campaigners well linked to EU politics, whereas outsiders were more likely to introduce topics that challenged the direction of travel of EU public policy (Bouza Garcia and Greenwood, 2014). Greenwood and Tuokko found a notable reach of campaigns in central and East European countries (Greenwood and Tuokko, 2017). All these features make the $\mathrm{ECl}$ an added value attempt to stimulate transnational public debate. Van de Steg argues that 'public spheres emerge through the public debate of controversial issues...the more we debate issues, the more we engage each other in our public discourses, the more we actually create political communities; (van de Steeg, 2010, p.39). The $\mathrm{ECl}$ does not by itself create a new European public sphere, but it does enable citizens to debate the same issues at the same time across national boundaries, which is one of the pre-conditions that Habermas sets for the formation of a transnational public sphere (Habermas, 1995). Moreover, it has certainly taken EU politics outside of the 'Brussels bubble'.

The European Commission has been keen for the $\mathrm{ECl}$ to work in a number of ways. It is one of the ten strategic priorities of the Juncker Commission. Successful initiatives have their measure placed on the 
agenda of the College of Commissioners. The Commission provides a translation service for each of the EU's 24 official languages. The Commission will part-register initiatives where only part of it falls within the legal competency for the EU to act, rather than refusing registration entirely to those initiatives where part falls outside of Treaty competencies. Moreover, in the early days of the measure, the Commission lent its servers to campaigners collecting signatures. In its 2017 legislative reform proposal, new measures include harmonising the age of eligibility to sign an initiative to 16 years (currently only done in Austria), and a common internet platform for signature collection which would enable the organisers of initiatives to communicate with their supporters.

\section{Conclusion}

'An open and structured dialogue between the Commission and special interest groups' has gradually been built since the 1990s, accelerating from the 2001 White Paper on Governance. The procedures to deliver this share a core denominator of transparency. The Transparency Register makes it known to the public who these groups are, what they are doing, and how many resources they are devoting to lobbying. Consultation procedures make known the responses received, and how the Commission reacts to them. Moreover, the Access to Documents measure empowers civil society organisations to acquire documents from EU Institutions within 15 days of asking for them, addressing asymmetries and enabling an elite public to keep political institutions accountable. A system of 
funding makes a teeming population of NGOs possible at EU level, apparently without instrumentalising NGOs, providing checks and balances upon producer organisations, and upon EU institutions themselves, playing the role of 'unofficial opposition' in an otherwise consensus bound system. NGOs are ready partners for EU institutions in an era when the EU agenda has shifted from market making to market regulating, providing political support as well as expert information. This axis has delivered European integration (Green Cowles, 1995). NGOs provide a proxy for an otherwise absent civil society, enabling the fulfilment of Article 11 on the Treaty on European Union for 'an open, transparent and regular dialogue with representative associations and civil society'. A mature landscape of coalition between NGOs is evident. All of the measures for 'an open and structured dialogue' have aimed at resembling a participatory democracy based around a market place of ideas built on pluralist principles, whilst at the same time seeking to filter out the worst that 'lobbying' can bring to a political system. The weight of evidence suggests that the EU political system has avoided biased representation, with regulatory policies in which the EU specialises typically producing competitive interest group politics, and a multi-level governance system that defies routine regulatory capture by any one type of special interest. An innovation to EU participatory democracy involves the European Citizens' I nitiative, introduced by the Lisbon Treaty, which has opened up a new channel of dialogue between EU institutions and civil society which is not dependent upon organised civil society in the 'Brussels bubble' to operationalise it. Whilst the $\mathrm{ECl}$ has no powers of mandate, it has broadened the EU policy agenda, and brought EU debates, sometimes 
contentious, directly to citizens in the member states, with over 8 million citizen signatures to initiatives, and numerous more conversations to achieve those signatures. It is an added value addition to a pluralist system of interest intermediation at EU level. 


\section{References}

Bouwen, P (2004) 'Exchanging access goods for access: A comparative study of business lobbying in the European Union institutions', European Journal of Political Research, 43: 337-369.

Bouza Garcia, L and Greenwood, J (2014) The European Citizens' Initiative: A new sphere of EU politics? Interest Groups \& Advocacy, 3, 3: 246-267.

Bunea, A and I benskas, R (2015) 'Quantitative Text Analysis and the study of EU lobbying and interest groups', European Union Politics, 16, 3: 429-455.

Coen, D (2013) Chameleon pluralism in the EU: an empirical study of the European Commission interest group density and diversity across policy domains, J ournal of European Public Policy, 20, 8: 1104-1119.

Compston, H and Greenwood, J (2001) Social Partnership in the European Union (Basingstoke: Palgrave Macmillan).

Costa, O and Brack, N (2018) How the EU Really Works (London: Taylor \& Francis). 
Dür, A and De Bièvre (2007) 'The Question of Interest Group Influence', Journal of Public Policy, 27, 1: 1-12.

Dür A, Bernhagen P and Marshall D (2015) 'Interest Group Success in the European Union: When (and Why) Does Business Lose?' Comparative Political Studies, 48, 8, 951-983.

Eising, R (2008) 'Interest Groups in EU Policy Making’, Living Reviews in EU Governance, http://www.europeangovernance-

livingreviews.org/Articles/Ireg-2008-4/ accessed on 25 September 2018.

EurActiv (2011) Experts strive to make citizens' initiative work, https://www. euractiv.com/section/public-affairs/news/experts-strive-tomake-citizens-initiative-work/ accessed on 8 October 2018.

European Commission (1992) 'An Open and Structured Dialogue between the Commission and Special Interest Groups',

https://publications. europa.eu/en/publication-detail/Lpublication/a9e0a8b1-5fa4-42bb-a7d7-c77640d81f78/language-en accessed on 11 September 2018.

European Commission (1997) 'Communication from the Commission on Promoting the Role of Voluntary Organizations and Foundations in Europe', http://aei. pitt.edu/6976/ accessed on 11 September 2018. 
European Commission (2000) 'The Commission and non-Governmental Organizations: Building a Stronger Partnership',

https://ec. europa.eu/europeaid/commission-discussion-paper-

commission-and-non-governmental-organisations-building-stronger_en Accessed on 21 September 2018.

European Commission (2001) ‘European Governance: A White Paper’, https://ec.europa.eu/europeaid/european-governance-white-paper_en accessed on 11 September 2018.

European Commission (2017) Report from the Commission on the application in 2016 of Regulation (EC) No 1049/2001 regarding public access to European Parliament, Council and Commission documents, https://eur-lex.europa.eu/legal-

content/EN/TXT/?uri=CELEX\% 3A52017DC0738 accessed on 11 September 2018.

European Commission (2018a) Better Regulation: why and how, https://ec. europa.eu/info/law/law-making-process/planning-andproposing-law/better-regulation-why-and-how_en accessed on 12 September 2018.

European Commission (2018b) Regulatory Scrutiny Board Annual Report 2017, https://ec. europa.eu/info/sites/info/files/rsb_factsheetv7mar_en_0.pdf accessed on 20 September 2018. 
European Parliament Research Service (2015) The European Citizens' I nitiative: the experience of the first three years, PE536.343

http://www. europarl. europa.eu/thinktank/en/document. html?reference=E PRS IDA(2015)536343 accessed on 9 October 2018.

European Parliament (2017) Report: Transparency, accountability and integrity in the EU institutions (2015/2041, INI, Committee on Constitutional Affairs, 30.3.2017, http://www.europarl. europa.eu/sides/getDoc.do?pubRef=-

//EP//TEXT+REPORT+A8-2017-0133+0+DOC+XML+V0//EN accessed on 27 September 2018

Falkner, G (1998) EU Social Policy in the 1990s: towards a corporatist policy community (London: Routledge).

Gorges, M (1996) Euro-corporatism? Interest intermediation in the European Community (Lanham, MD: University Press of America).

Gornitzka, A and Sverdrup, U (2011) 'Access of Experts: Information and EU Decision-making', West European Politics, 34: 1, 48-70.

Green Cowles M G (1995) 'Setting the Agenda for a New Europe: The ERT and EC 1992', J ournal of Common Market Studies, 33, 4, 501-526.

Greenwood, J. (2002) Inside the EU Business Associations (Basingstoke: Palgrave Macmillan). 
Greenwood J, Grote J and Ronit K (1992) Organized Interests and the European Community (London: Sage).

Greenwood, J (2014) 'Interest Groups and Patterns of Lobbying in Brussels', in J Magone (ed.) Handbook of European Politics (London: Routledge), chapter 43, pp797-809.

Greenwood, J (2017, 4 $4^{\text {th }}$ edtn. ) Interest Representation in the European Union (Basingstoke: Palgrave Macmillan).

Greenwood, J and Tuokko, K (2017) 'The European Citizens' I nitiative: the territorial extension of a European Political Public Sphere?' European Politics \& Society, 18, 2, 166-181.

Greenwood, J (2019) 'The European Citizens' Initiative: Bringing the EU Closer to its Citizens?', Comparative European Politics,

Habermas, J. (1995) Comment on the paper by Dieter Grimm, 'Does Europe Need a Constitution'? European Law J ournal 1(3): 303-307

Hannan, D (2010) A Doomed Marriage: Britain and Europe (London: Notting Hill Editions). 
Hart, D (2010) 'The Political Theory of the Firm', in David Coen, Wyn Grant and Graham Wilson (2010) (eds.) The Oxford Handbook of Business and Government (Oxford: Oxford University Press), chapter 7.

Hoff A., Lelieveldt $H$ and van der Does $R$ (2016) 'A biased rapporteur or politics as usual? Reassessing the balance of interests in the EU food information labelling case', J ournal of European Public Policy, 23, 2: 296313.

Inter Institutional Agreement on a mandatory register for lobbyists, http://www. europarl. europa.eu/legislative-train/theme-union-ofdemocratic-change/file-inter-institutional-agreement-on-a-mandatorytransparency-register-for-lobbyists

Accessed on 9 October 2018

Karatzia, A. (2017) 'The European Citizens' Initiative and the EU institutional balance: on realism and the possibilities of affecting EU lawmaking'. Common Market Law Review 54(1): 177-208.

Klüver, H (2012) Biasing Politics? ‘Interest Group Participation in EU Policy-Making', West European Politics, 35, 5, 1114-1133.

Klüver, H (2013) Lobbying in the European Union: Interest Groups, Lobbying Coalitions and Policy Change (Oxford: Oxford University Press). 
Klüver, H (2015) 'The promise of quantitative text analysis in interest group research: A reply to Bunea and Ibenskas', European Union Politics, 16, 3: $456-466$.

Klüver H, Braun C and Beyers J (2015) 'Legislative lobbying in context: towards a conceptual framework of interest group lobbying in the European Union', J ournal of European Public Policy, 22, 4:447-461.

Kohler Koch, B (2010) 'Civil Society and EU Democracy: Astroturf Representation?', J ournal of European Public Policy, 17, 1: 100-17.

Kohler Koch. B (2012) ‘Post Maastricht Civil Society and Participatory Democracy', J ournal of European Integration, 34, 7: 809-24.

Kohler Koch, B and Quittkat, C (2013) Demystification of Participatory Democracy: EU Governance and Civil Society (Oxford: Oxford University Press).

Kurzer, P and Cooper, A (2013) Biased or not? Organized interests and the case of EU food information labelling, Journal of European Public Policy, 20, 5: 722-740.

Mahoney, C (2007) Lobbying Success in the United States and the European Union, Journal of Public Policy, 27, 1:35-56. 
Mazey, S and Richardson, J (2005) 'Environmental Groups and the

European Community: Challenges and Opportunities', in A Jordan (ed.)

Environmental Policy in the European Union (London: Earthscan): 106-21.

Obradovic, D (1995) Prospects for Corporatist Decision-Making in the European Union: the Social Policy Agreement, Journal of European Public Policy, 2, 2: 261-283.

Quittkat, C (2011) 'The European Commission's Online Consultations: A Success Story?' J ournal of Common Market Studies, 29, 3: 659-74

Rasmussen, M (2014) The Battle for Influence: The Politics of Business Lobbying in the European Parliament, J ournal of Common Market Studies, $53,2,365-382$.

Roederer-Rynning, C and Greenwood, J (2017) 'The European Parliament as a developing legislature: coming of age in trilogues?' J ournal of European Public Policy, 24, 5: 735-754.

Sanchez Salgado, R. (2014) ‘Rebalancing EU Interest Representation? Associative Democracy and EU Funding of Civil Society Organizations', J ournal of Common Market Studies, 52, 2: 337-53.

Schmidt, V (2001) 'Democracy and Legitimacy in the European Union Revisited: Input, Output and 'Throughput', Political Studies, 61, 2-22. 
Streeck, W and Schmitter, P C (1991) 'From National Corporatism to Transnational Pluralism: Organized Interests in the Single European Market', Politics and Society, 19, 2: 133-65.

Van de Steeg, M. (2010) Theoretical reflections on the public sphere in the European Union: A network of communication or a political community? In: Cristiano Bee and Emma Bozzini (eds.) Mapping the European Public Sphere: Institutions, Media and Civil Society (Farnham: Ashgate), pp.3045.

Vassalos, Y (n.d.) Expert Groups - letting corporate interests set the agenda? https://www.alter-eu.org/sites/default/files/bbb-chap-06.pdf accessed on 20 September 2018.

Vogiatzis, N. (2017) 'Between discretion and control: Reflections on the institutional position of the Commission within the European citizens' initiative process', European Law J ournal, 23(3-4): 250-271.

Young, A R (2010) 'The Politics of Regulation and the Internal Market', in K E J ørgensen, Mark Pollack and Ben Rosamond (eds.) Handbook of European Union Politics (London: Sage), pp 373-394. 


\section{Further Reading}

Bouwen, P (2004) 'Exchanging access goods for access: A comparative study of business lobbying in the European Union institutions', European Journal of Political Research, 43: 337-369.

Coen, D (2013) Chameleon pluralism in the EU: an empirical study of the European Commission interest group density and diversity across policy domains, J ournal of European Public Policy, 20, 8: 1104-1119.

Dialer, D and Richter, M (eds.) Lobbying in the European Union: Strategies, Dynamics and Trends (Springer)

Klüver, H (2013) Lobbying in the European Union: Interest Groups, Lobbying Coalitions and Policy Change (Oxford: Oxford University Press).

Dür A (2008) Measuring Interest Group Influence in the EU: A Note n Methodology, European Union Politics, 9, 4: 559-576

Dür, A and De Bièvre (2007) 'The Question of Interest Group Influence', J ournal of Public Policy, 27, 1: 1-12.

Dür, A and Mateo, G (2014) Public opinion and interest group influence: how citizen groups derailed the Anti-Counterfeiting Trade Agreement, Journal of European Public Policy, 21, 8, 1199-1217 
Dür A, Bernhagen P and Marshall D (2015) 'Interest Group Success in the European Union: When (and Why) Does Business Lose?' Comparative Political Studies, 48, 8, 951-983.

Eising, R (2008) 'Interest Groups in EU Policy Making’, Living Reviews in EU Governance, http://www.europeangovernance-

livingreviews.org/Articles/Ireg-2008-4/ accessed on 25 September 2018.

Greenwood, J (2007) 'Organised Civil Society and Democratic Legitimacy in the EU', British Journal of Political Science, 37:2, 333-357

Greenwood, J (2017, $4^{\text {th }}$ edtn) Interest Representation in the European Union (Basingstoke: Palgrave Macmillan)

Klüver H, Braun C and Beyers J (2015) 'Legislative lobbying in context: towards a conceptual framework of interest group lobbying in the European Union', J ournal of European Public Policy, 22, 4:447-461.

Kohler Koch, B and Quittkat, C (2013) Demystification of Participatory Democracy: EU Governance and Civil Society (Oxford: Oxford University Press).

Sanchez Salgado, R. (2014). Europeanizing civil society: how the EU shapes civil society organizations. (Basingstoke: Palgrave Macmillan). 